\title{
Psychological and Cultural Borderlands in Tayyib Salih's Season of Migration to the North
}

\author{
Hussein Hasan Zeidanin \\ Department of English, College of Arts, Tafila Technical University, P.O. Box 179, Tafila 66110, Jordan \\ Email: husseino_z@yahoo.com
}

Doi:10.7575/aiac.alls.v.7n.1p.75

URL: http://dx.doi.org/10.7575/aiac.alls.v.7n.1p.75
Received: 08/09/2015

Accepted: 04/11/2015

\begin{abstract}
This paper explores the conflicting points of view of the narrator and Saeed in Tayyib Salih's novel. Their conflict emanates from psychological and ideological sources and foreshadows their relations with the western civilization and women. While some scenes and events of the novel introduce Saeed as an alter ego or double of the narrator for their identical social, cultural and educational backgrounds, others represent him as an id that needs to be regulated and controlled by the narrator who plays the role of the ego. The paper further contends that Saeed is neither a nationalist nor assimilationist; rather, he is a culturally hybrid character who equally identifies with the occidental culture of England and the oriental culture of Sudan. His latent hatred, mistrust and enmity towards the occident can be considered ironic or parodic on the ground that he vigorously seeks to import the western values of modernism, urbanization, egalitarianism and enlightenment to Sudan.
\end{abstract}

Keywords: Double, consciousness, unconsciousness, hybridity, mimicry, narcissism

\section{Introduction}

Tayyib Salih's Season of Migration to the North addresses such postcolonial themes as nostalgia to the pre-colonial era, questioning of orientalism and imperialism, formation of double consciousness and cultural hybridity which the controversial relationship between the narrator and Mustafa Saeed epitomizes. Du Bois (1990) uses the term "double consciousness" to describe the multiple facets of the African American identity. He defines it as "a peculiar sensation, this double-consciousness, this sense of always looking at one's self through the eyes of others... One ever feels his two-ness, - an American, a Negro; two souls, two thoughts, two unreconciled strivings; two warring ideals in one dark body" (8-9). In the light of this perception, I am going to explore the psychological and cultural borderlands in Season, where incompatible cultural and psychological elements coexist in the characters of Mustafa Saeed and the narrator. A psychoanalytic reading of the novel will make it easier to understand the complex relationships between Saeed and the narrator, Saeed and women, and Saeed and the west. The motives steering a character's actions or decisions will be diagnosed based on Freud's concepts of unconsciousness and repression. Because the novel is set in the postcolonial history and culture of Sudan, I will critically analyze it in the light of Homi Bhaba's postcolonial theory of cultural hybridity, and argue that Saeed is a hybrid rather than a fundamentalist or nationalist.

\subsection{Novel Overview}

Season is a novel Tayyib Salih originally wrote in Arabic and published in 1966. It tells the story of an unnamed narrator who returns to Wad Hamid, a small village in northern Sudan, from Britain where he has studied English poetry for seven years. Among the crowd of villagers who welcome him home is an anonymous middle-aged man named Mustafa Saeed. The narrator asks his grandfather about Saeed; and he tells him that Saeed has moved from Khartoum to the village for five years and married Hosna Bint Mahmoud, a woman from the village. While in a drinking session with his friend, Mahjoub, the narrator meets Saeed who gets drunk and begins to recite English poetry. The narrator gets shocked as he thought he was the only one to speak English and study English poetry in the village. Saeed will tell his life story to nobody but to the narrator who promises not to confide it to anyone. Saeed reveals that he was born to a widowed poor mother in Khartoum, where he grew up and received his elementary education. In reward for his genius and learning potentials, the headmaster of his school enrolled him at a secondary school in Cairo, where he came to know Mr. Robinson and his wife who proved to be loving and generous enough to teach, host and support him financially. As soon as he graduated, he was awarded a scholarship to study English poetry at Oxford. In the meantime, he made up stories about the charms of Sudan and Africa to seduce English women. He caused heart break to his three girl friends - Ann Hammond, Sheila Greenwood and Isabella Seymour - and murdered Jean Morris, his English wife. He was convicted of murder and sentenced to seven years in prison.

Then the narrator tells us that Saeed mysteriously disappeared in the Nile River, where he possibly committed suicide during a flood. Following his disappearance, the narrator becomes the guardian of Saeed's estates, two sons and widow, Hosna, whom he falls in love with but never marries. The narrator will later discover that all of Saeed's secrets and unanswered mysteries have been locked in the private room of his house, where he finds English books, photographs of 
his English girl friends, and a portrait of his English wife. Towards the end of the novel, the narrator contemplates suicide in the Nile River, but he is suddenly held back by a desire for a cigarette. Hence, he swims towards the shore and begins to shout for help.

\section{Psychological Borderlands}

Mustafa Saeed's psychological identity is so indistinguishable from that of the narrator's that Patricia Geesey (1997) considers Saeed as the narrator's alter ego or double in her argument that "the narrator is so obsessed with Saeed's past and distracted by Saeed's legacy that he can barely distinguish between his own identity and that of Saeed. (129). The similarities in their experiences instantiate that argument because both leave Sudan to England for seven years, speak English and study English poetry; both superficially interact with the western culture as it is suggested by the narrator who admits that "I too had lived with them. But I lived with them superficially, neither loving nor hating them" (49); both undergo the prison experience in England, which the narrator portrays as a physical prison for Saeed and a metaphorical prison for him where he suffered loneliness and endured darkness. In this sense, the narrator recalls that

For seven years I had longed for them, had dreamt of them, and it was an extraordinary moment when I at last found myself standing amongst them... and it was not long before I felt as though a piece of ice were melting inside me, as though I were some frozen substance on which the sun had shined. (1)

Both seek salvation in the river Nile, where it is thought that Saeed commits suicide and the narrator meets his mysterious fate. The narrator eloquently describes their indistinguishable experiences and wonders "was it likely that what happened to Mustafa Saeed could have happened to me? He had said that he was a lie, so was I also a lie? I am from here - is not this reality enough?" (49).

In addition to their shared experiences, the narrator reveals that Saeed "had become an obsession that was ever with me in my comings and goings" (61). Mohammed Siddiq (1978) perceives the narrator's unconscious attraction to Mustafa Saeed and his inability to forget or stop thinking of him as "characteristics of the double" (86). This explains why Saeed's silence and smiles do not bewilder the narrator who, in his recollection of the day he arrived the village, notices that "Saeed was silent ... He had listened in silence, sometimes smiling; a smile which, I now remember was mysterious, like someone talking to himself" (3-4). Saeed's silence during the narrator's discussion of the cultural differences between Europe and Sudan with the villagers shows that he already knows and approves whatever the narrator says to the villagers.

That the narrator becomes the guardian of Saeed's legacy, lover of his widow, provider for his children, and keeper of his secrets defines him as a double. When the narrator unlocks the door and enters the private room, where Saeed has hidden his secrets and life story for a very long time, he momentarily mistakens his own reflection in the mirror for the image of Saeed. He recollects that

The light exploded on my eyes and out of the darkness there emerged a frowning face with pursed lips that I knew but could not place. I moved towards it with hate in my heart. It was my adversary Mustafa Saeed. The face grew a neck, the neck two shoulders and a chest, then a trunk and two legs, and I found myself standing face to face with myself. This is not Mustafa Saeed - it is a picture of me frowning at my face from a mirror (135).

The narrator's recollection signifies his identification with Saeed as a double though he sometimes fears and hates him as an id or rival. A number of narrative incidents instantiates their conflicting points of view. First, they debate over what the real needs of Sudan are; and the narrator gets extremely furious when Saeed blames him for studying the life of an obscure English poet instead of "agriculture, engineering or medicine" (9).

Second, each refers to the other as being an outsider or stranger to the village in particular and Sudan in general. Because Saeed is native to Khartoum, he remains a stranger in Wad Hamid; and he is not elected as the chairman of the agricultural committee despite the efforts he exerts to develop agriculture there. The narrator's grandfather still identifies Saeed "not (as) a local man but a stranger who had come here five years ago" (2). It seems that Saeed is destined to be a stranger to the village in life and death because after he dies, he "hadn't even found himself a grave to rest his body in" (54) but "in the bellies of the crocodiles" (46) in the Nile River.

Saeed, conversely, asserts his belonging to the village by using the inclusive pronoun "we", whereas he in several scenes addresses the narrator by the pronoun "you" to exclude him from the collective identity of the tribe and village. This stirs the narrator to protest "at the way Saeed says "we" and does not include me, though he knows that this is my village and that it is he - not I who is the stranger" (9).

Third, the narrator reproaches Saeed's egocentricity which, according to Tarawneh and Joseph (1988), can be understood in light of Freud's concept of "narcissism" as the ego takes "itself as object" and behaves "as though it were in love with itself" (331). What reveals Saeed's narcissistic behaviors and fantasies is his monologic confession that "this is a fact in my life: the way chance has placed in my path people who gave me a helping hand at every stage, people for whom I have no feeling of gratitude. I used to take their help as though it were some duty they were performing for me" (23). In another monologue, he discloses that: "I was wrapped up in myself and paid no attention to 
the love they showered upon me" (26). These revelations express his ingratitude to the English people despite the generous love and support he receives from them.

The narrator, however, portrays himself as a selfless person who traveled to the West not for selfish gain and glory but for transferring western knowledge and sciences into Sudan. As soon as he graduates, he returns to Sudan with the intention to:

give lavishly, I want love to flow from my heart, to ripen and bear fruit. There are many horizons to be visited, fruits that must be plucked, books read, and white pages in the scrolls of life to be inscribed with vivid sentences in a bold hand... I feel a sense of stability, I feel I am important, that I am continuous and integral. No I am not a stone thrown into the water but seed sown in a field (5).

That he is a "seed" rather than a "stone" signifies the fertility of his experiences and foretells a promising future for him in Sudan.

What appears as an external conflict between Saeed and the narrator can be reconceived as a projection of unconsciousness. Mohammed Siddiq (1978) considers all the characters in the novel as "projections of Mustafa Saeed's - or, better still, the narrator's - unconscious and all the events as having been enacted within his own psyche as latent potentialities" (85). Tarawneh and Joseph (1988) follow the same trajectory in his interpretation of Saeed's fantasies as "avenues of escape from his truly degrading present represented by Kitchener in the Sudan or Allenby in Jerusalem, into the golden ages of past Arab glory represented by the conquest of Andalusia" (342). This makes readers very skeptical of the truthfulness of events and the identities of the characters that might have existed only in the narrator's imagination. Such doubts are cast by Saeed during his trial in London when he stands up and shouts at the court: "This Mustafa Saeed does not exist. He is an illusion, a lie. I ask you to rule a lie be killed" (32). They are also confirmed by the narrator's disturbing thought that "Mustafa Saeed never happened, that he was in fact a lie, a phantom, a dream or a nightmare that had come to the people of that village one suffocatingly dark night, and when they opened their eyes to the sunlight he was nowhere to be seen" (46). Saeed and all the other characters in the novel are correspondingly mere fantasies which help the narrator avenge his colonial past and get relieved from his present postcolonial miseries.

\subsection{Dictates of Consciousness}

Saeed consciously projects the stereotypical images of meek and docile Arab women on the western women to justify his sadist and misogynist nature. Saeed is brought up in an Islamic conservative society, where women are subjugated, circumcised, veiled and subserviently devoted for satisfying the sexual desires of their husbands. While in England, he meets a different type of women who "knows no fear; they accept life with gaiety and curiosity" (37). As the model of free and autonomous western women poses a threat to his eastern manhood, he decides to avenge it by causing heartbreak to Ann Hammond, Sheila Greenwood and Isabella Seymour. His marriage from Jean Morris is more threatening because of the questions she raises about his jealousy which is widely viewed as the soul of manhood in oriental societies. Her suspicions whether he would feel jealous in case that she betrayed him with another man (162) extremely insulted and offended him. His self-assurance and manliness are also threatened when she contemptuously bares her breast and challenges him to "plunge the knife in" (158). When Saeed presses the dagger down between her breasts, she derives pleasure from it and astonishingly says: "I thought you would never do this. I almost gave up hope of you" (164). Accordingly, Saeed's sexual violence against western women can be interpreted as a conscious reaction towards the danger they pose to his manhood as an orient rather than a means to avenge the west for its imperial practices against Sudan.

\subsection{Dictates of Unconsciousness}

The oedipal complex appears to have a tremendous effect on Saeed's sexual and social relations which, according to Mohammed Siddiq (1978), "instead of being controlled by the conscious ego, whose function is to regulate the even flow of psychic energy and to maintain the individual's psychic balance, the mother complex here has subordinated the ego to its unruly caprices" (77). Unlike the narrator, Saeed fails in that respect due to lacking communication with his mother. What he can still remember about his mother are "her thin lips resolutely closed, with something on her face like a mask, I don't know a thick mask as though her face were the surface of the sea." (19). The mother's closed lips suggest she rarely speaks to him, whereas her masked face betokens their apathetic and dispassionate relationship which the scene of bidding farewell to each other when Saeed was about to leave to Cairo exemplifies.

Nevertheless, the oedipal complex provokes his repressed incestuous phantasies and impulses towards his mother as it is denoted in his confession that "at the climax of our (sexual) pain there passed through my head clouds of old far off memories" (44). These clouds imply that Saeed sees the image of his mother in the faces of women he dates, befriends or makes love with. Significantly relevant here is his sexual attraction to Mrs. Robinson who, by paying for his school, travel and living expenses in Cairo, assumes the role of his surrogate or adopted mother. His hug with her at Cairo Railway Station signifies his first experience of hugging a woman, an experience that moved him sexually at an early age of twelve. In his description of the feelings he had at that moment, Saeed reveals that

All of a sudden I felt the woman's arms embracing me and her lips on my cheek. At that moment, as I stood on the station platform amidst a welter of sounds and sensations, with the woman's arms round my neck, her mouth on my cheek, the smell of her body - a strange 
European smell- tickling my nose, her breast touching my chest, I felt- I, a boy of twelve- a vague sexual yearning I have never previously experienced (25).

Saeed's sexual obsession with Mrs. Robinson continues from childhood to adulthood when he smells her odor in the bodies of his three English girl friends: Sheila, Isabella and Ann ( 37). The effect of the oedipal complex continues towards the end of the novel when Saeed views Mrs. Robinson more as a mother than a lover or sexual object. In the court scene after Saeed is sentenced to prison, he weeps on her breast like a baby seeking his mother's comfort and protection and "she stroked his head, kissed him on the forehead, and said don't cry, dear child" (112).

\section{Cultural Borderlands}

Cultural hybridity, as Homi Bhabha (1994) constructs it, "unsettles the mimetic demands of colonial power" (154) and uses the very ethos and ideologies of colonial and anticolonial powers to discursively modify their ethnocentric representations of and rhetoric about each other and create a tolerant and pluralist third culture with which diasporic subjects and natives of the colonized nations ambivalently identify.

The narrator's double, Saeed, epitomizes the ambivalence and heterogeneity of the hybrid postcolonial culture because he identifies himself neither as a proponent of the Sudanese culture nor an opponent of the Western imperial culture. On one hand, Saeed criticizes the western imperial culture for using the ideals of enlightenment and modernity as pretexts to "lay waste and plunder" (94) the natural resources of Africa in general and Sudan in particular. In the court scene, he reminds judges and lawyers of the British imperial campaigns which Edmund Allenby led in 1917 to conquer Egypt, Palestine and Jordan. He admonishingly and accusingly said that "the ships at first sailed down the Nile carrying guns not bread, and the railways were originally set up to transport troops; the schools were started so as to teach us how to say "yes" in their language. They imported to us the germ of the greatest European violence" (95). On the other hand, he attacks the patriarchal culture of Sudan which commodifies and objectifies women and engenders tribal hierarchies and dynasties or creates new ones. On this account, Saeed disapproves polygamy, circumcision of women, and men's overuse of the divorce vow oftentimes for nefarious reasons like "when Mahjoub swore he would divorce if he did not (sit)" (13).

Saeed's attitudes towards both the Sudanese culture and the English culture introduce him as a culturally hybrid person seeking to produce a pluralistic cultural matrix by means of creolization and hybridization, exactly as he does with his double fruit tree whose some branches "produce lemons, others oranges" (15). In the comparison John E. Davidson (1989) conducts between Salih's Season and other neocolonial African novels, he finds out that "Season goes beyond a simple rejection of the European invasion and legacy. It offers a stunning critique of cultural segregationist moods by exposing in Sudanese culture the oppression that predated the British intrusion" (385). Saeed accordingly asserts his rejection of the essentialist and binary ideologies of nationalism and imperialism and his assumption of a hybrid identity as it is expressed in his autobiography which is ironically dedicated "to those who see with one eye, speak with one tongue and see things as either black or white, either eastern or western" (150-151). This irony apparently shows that Saeed is neither black nor white, neither wholly eastern nor wholly western. Rather, he transcends binary constructions of identity which essentially classify people into black and white, nations into civilized and uncivilized, languages and cultures into developed and developing; and he embraces a hybrid identity that respects and tolerates racial, ethnic and gender differences. His marriage from a white woman, Jean Morris, can be considered one marker of his hybridity, especially that he views himself as the: "South that yearns for the North and the ice" (30). Saeed's frequent references to Othello is another marker of his hybridity. During his trial for charges related to the murder of Jean Morris, Saeed declares that "I am the desert of thirst. I am no Othello. I am a lie. Why don't you sentence me to be hanged and so kill the lie?" (33). He also refers to Othello during his game of seduction with Isabella Seymour who asks him "What race are you, are you Arab or African?" Saeed answers her question by assuming both races: "I am like Othello - Arab African" (38). For Patricia Geesey (1997), "Saeed's invocation of Othello either as a weapon of seduction or as a mental note expressed in his defense is a pivotal concept for understanding the notion of cultural contagion" (134).

The balance the narrator and his double seek to maintain between the traditions of a tribal and agricultural society in Sudan and the products of a modern industrial society in England is a third manifestation of their hybridity. In his comparison of the present and past states of the precolonial and postcolonial societies, Saree Makdisi (1992) indicates that

While the narrator represses the realization and the knowledge that the precolonial world has been irrevocably changed, Mustafa Saeed acknowledges these changes and incorporates them into himself. If the narrator tries to retrieve the precolonial past while dreaming of the postcolonial future, Mustafa tries to bind together the past and present (811).

This suggests that both Saeed and the narrator combine the traditions of the past with the modernity of the present and future. They, for instance, get impressed by the sight of "people on donkeys and others on foot, while out from the bank opposite the landing stage little boats and sailing ships set forth" (62-63). In this scene, modern and traditional elements are concretely merged. They also appreciate the high productivity of modern technology which has led to the replacement of the water wheels on the bank of the Nile "by pumps, each one doing the work of a hundred waterwheels" (4). However, they believe that the Sudanese government should interfere to protect national industries from foreign competition like when: "the market for water-wheels dried up with the coming of pumps" (70). The absence of 
such a protective strategy in Sudan results in the bankruptcy of Wad Baseer, who no longer makes water-wheels despite his long experience in that industry.

Modernization, urbanization, enlightenment and development are among the ideals of the western civilization which Saeed and the narrator pursue and seek to equip Sudan with. This is why the narrator advises villagers not to destroy the "railways, ships, hospitals, factories and schools" (49) which the colonizer has constructed and left behind. Instead, he encourages them to enroll their children at schools, visit physicians, work for factories and use modern means of transportation; his reference to hospitals suggests his preference of scientific medicine to folk medicine. He preaches that villagers should speak English "without either a sense of guilt or a sense of gratitude" (49) because learning foreign languages is necessary for their cultural, social and economic development. He accentuates that the present culture and history of Sudan are intertwined with the colonial culture and history, so he warns villagers not to let their nostalgic reverence to the past "poison" (49) their present or future.

Socially, both the narrator and Saeed believe that women in Sudan are oppressed, subordinated to men, and denied freedoms of expression, choice and thinking, and rights of education, work and equality. Repelled by gender-based violence and discrimination, they commit themselves to reform gender relations and redefine gender roles. Saeed, for instance, sets himself as an example of "a generous husband and a generous father" (90) who helps Hosna produce an "indescribable change" (101). Hosna develops from a traditional village woman into an independent urbanized woman following their marriage. After Saeed dies, Hosna will become an agent of change who existentially resists the constraints of patriarchy and protests against male guardianship and social injustices. When she is forced to marry Wad Rayyes who views women as donkeys, she determines to kill him and commit suicide. Hosna's tragic death introduces her as an existentialist heroine according to Mona Takieddine (1985) who states that "Season reads as the existential fable of Arab man and woman in search of identity, a place in the universe, a meaning in life" (26).

\section{Conclusion}

Season psychologically examines the conflict between consciousness and unconsciousness which is respectively personified by the characters of the narrator and Saeed. Their identical cultural, social and educational backgrounds account for identifying Saeed as a double or alter ego of the narrator. Yet, they develop discordant attitudes towards the west. Their discord arises from the dictates of consciousness and the drives of unconsciousness. While they consciously view the west as an enemy that needs to be battled and defeated, they unconsciously consider it as a friend or an ally whose knowledge, technologies and sciences should be borrowed and transferred. Though Saeed's words and deeds introduce him as an invader of the West, he is a cultural hybrid who neither belongs to the east nor to the west. Instead, he seeks to combine both civilizations in his schemes for the reformation, modernization and development of Sudan.

\section{References}

Bhabha, H. (1994). The Location of Culture. London: Routledge.

Davidson, J. (1989). In Search of a Middle Point: The Origins of Oppression in Tayeb Salih's "Season of Migration to the North". Research in African Literatures, 20(3), 385 - 400.

Du Bois, W.E.B. (1990). The Souls of Black Folk. New York: Vintage.

Geesey, P. (1997). Cultural Hybridity and Contamination in Tayeb Salih's "Mawsim al-hijra ila al-Shamal (Season of Migration to the North). Research in African Literatures, 28 (3), 128-140.

Makdisi, S. S. (1992). The Empire Renarrated: "Season of Migration to the North" and the Reinvention of the Present". Critical Inquiry, 18(1), 804-820.

Salih, T. (1997). Season of Migration to the North. (J. Denys, Trans.). Boulder: Lynne Rienner Publishers.

Siddiq, M. (1978). The Process of Individuation in Al-Tayyeb Salih's Novel Season of Migration to the North. Journal of Arabic Literature, 9(1), 67-104.

Takieddine, M. (1985). Images of Arab Women in Midaq Alley by Naguib Mahfouz, and Season of Migration to the North by Tayeb Salih". International Journal of Middle East Studies, 17(1), 25-36.

Tarawneh, Y. and Joseph J. (1988). Tayeb Salih and Freud: The Impact of Freudian Ideas on Season of Migration to the North. Arabica, 35(3), 328-349. 